\title{
Miranda
}

Revue pluridisciplinaire du monde anglophone /

Multidisciplinary peer-reviewed journal on the English-

speaking world

1 | 2010

Variations on Darwin

\section{Labyrinths and Horizons: Textual Space in The Good Soldier}

Ellen Levy

\section{OpenEdition}

\section{Journals}

Electronic version

URL: http://journals.openedition.org/miranda/772

DOI: $10.4000 /$ miranda. 772

ISSN: 2108-6559

Publisher

Université Toulouse - Jean Jaurès

\section{Electronic reference}

Ellen Levy, "Labyrinths and Horizons: Textual Space in The Good Soldier", Miranda [Online], 1 | 2010

Online since 23 March 2010, connection on 16 February 2021. URL: http://journals.openedition.org/ miranda/772 ; DOI: https://doi.org/10.4000/miranda.772

This text was automatically generated on 16 February 2021.

\section{cc) (i) () $\Theta$}

Miranda is licensed under a Creative Commons Attribution-NonCommercial-NoDerivatives 4.0 International License. 


\title{
Labyrinths and Horizons: Textual Space in The Good Soldier
}

\author{
Ellen Levy
}

1 Primitive European painting, Byzantine mosaics and the contrapuntal music of Bach, wrote Ford Madox Ford, must not be taken as literal forms but rather as "abstract variations on an aesthetic, given theme" (Ford 1986, 354). It would perhaps not be unfair to say that Ford's own great fugue, The Good Soldier, is not to be taken literally either. There are too many self-contradictions, chronological anomalies, admissions of faulty recollection, outrageous assertions, high-handed rejections of cognition, failed anagnorises, lapses of logic, flauntings of riddles, ticklings with ironic intent (from the title onwards), for the reader-who is solicited as a participant-reconstructionist from the narrator's very first use of the word "you" - to be in doubt about the interpretative task that lies ahead of him. ${ }^{1}$

2 In a novel that features a narrator writing in what he wishes to be a spoken style, telling a "real" story in an elaborately fabricated setting, convincingly formulating incompatible hypotheses for which he refuses to take responsibility, oscillating regularly between former ignorance and informed retrospection, a stance doubled by an inability to interpret from either perspective, confronting two cultural outlooks (the English and the American) while apparently adhering to or comprehending neither, hesitation becomes more than an occasional epistemological stance: it is, to paraphrase Samuel Hynes, elevated to the rank of a structural principle (Hynes 311). If all mimetic external space (or physis) functions with greater or lesser transparency as projected mentality (or psyche, Levenson 7), Ford Madox Ford's novel operates a phenomenal compression, conflating physis and psyche so thoroughly that external and internal worlds are reversibly imprinted, they flow one into the other in a configuration which J. Hillis Miller calls "anastomosis." ${ }^{2}$ Where the mind of Ford's narrator Dowell ends and the world begins is a moot point: Dowell paints a material world that is the projection of an inner landscape, and his text does not so much contain the oddities and ambivalences of his mental universe as it becomes their materialisation. 
What is more, Dowell's discourse, if not his method, is largely mediated by cultural borrowings, adding a supplementary layer of complexity to the relationship world/ mind. When, for example, Dowell presents the protagonists of his "tale of passion," he "justifies" them- "justification" of character being a tenet of Ford's literary impressionism-by providing information about their social background and place of origin. In describing the inhabitants of the Connecticut town of which his wife Florence is a native, Dowell claims that "they are more old-fashioned than even the inhabitants of Cranford, England, could have been" (10), thereby confounding realist motivation and a literary model that is meant to underwrite verisimilitude but paradoxically undermines it. Furthermore, this link having been established, other subtle and amusing references to Mrs Gaskell's 1853 novel recur at varying intervals throughout The Good Soldier. ${ }^{3}$

4 Such lines of connection, which I will attempt to place in the context of the novel's labyrinthine structure, abound: they are figured, for example, in the wider geography of the novel, with its narrator crossing sealines between three land masses-America, Britain and Continental Europe-the latter functioning as a sort of air-lock in which members of the two communities can mix and mingle, without the danger of cultural asphyxiation. A resident of a sort of expatriate no-man's land, a "wanderer," as he calls himself, "upon the face of public resorts" (21), Dowell-his name, of course, also suggests linkages-is the perfect spokesman for the sense of permanent displacement, psychic and geographical, that the narrative offers as commensurate with its sense of being always elsewhere and "elsewhen" (to use a favourite Fordian expression). Dowell finds both his abandoned homeland and the Britannia to which he aspires "amazing" $(20,21,102,103)$-complementary in their incomprehensibility: if, for example, America is filled with the energy of a baffling spirit of enterprise, England is prodigious in its ineffable sense of repose-both impressions proving, by the way, in the long run, altogether deceptive. These places are perhaps less significant in the separateness of their national characteristics (in any case, human nature remains enigmatic regardless of continent) than, with their inscriptions of boatlines, trainlines, carriage routes, and bridle paths, as a figure for the continua that both measure the distance between entities and bridge the intervals between them. Thus, Dowell's ineffectual geographical crossings and re-crossings, undertaken with only a frail ancestral wampum deed to his Philadelphia farm to bolster his identity, never lead him to anchorage, always bring him back to an emotional starting point that is also a dead end, conferring movement but precluding destination-and this is no less true for the circumnavigation of the globe undertaken by his wife Florence, her Uncle John and the young man called Jimmy, a voyage placed under the aegis of the uncle's spherical oranges and of his folding chairs that permit stasis in the midst of motion. To be lost in the labyrinth or to explore horizons, to be engulfed by torpor or to be restlessly ambulatory, become two modes of the same aporia. It is only in the act of composition-he is after all a descendant of the colonists led to America by William Penn-that Dowell can perform the doubling back that produces, if not meaning, at least a somewhat fruitful navigation between the shores of what was and those of what is.

5 If I may be allowed to use one last nautical image before coming definitively ashore, in one of the most frequently quoted of his several metatextual openings, Dowell announces the banner under which he intends to sail his narratological boat:

I have, I am aware, told this story in a very rambling way so that it may be difficult for anyone to find their path through what may be a sort of maze. I have stuck to 
my idea of being in a country cottage with a silent listener, hearing between the gusts of the wind and amidst the noises of the distant sea, the story as it comes. And, when one discusses an affair-a long sad affair-one goes back, one goes forward. One remembers points that one has forgotten and one explains them all the more minutely since one recognises that one has forgotten to mention them in their proper places and that one may have given, by omitting them a false impression. I console myself with thinking that this is a real story and that, after all, real stories are probably told best in the way a person telling a story would tell them. They will then seem most real. (119-120)

6 I will leave aside the pleasantly labyrinthine feel of this paragraph and the jovial ambiguity of Dowell's wish to tell a "real" story so that it will "seem" true, confounding, as he does, the wish with the imagined wind and sea of a fictional situation of utterance that is nonetheless anchored in an extratextually existing locale, in order to consider the image of the maze which Dowell proffers as the emblem of his narratological difficulties but which also, rather helpfully, comes to serve as a guide to the perplexities of a tale whose centre the reader, created in the image of the narrator, may well find elusive.

7 Dowell presents himself as a seeker, among other things, of clues to the conundrum of women. They are to him "riddles" $(23,122)$, so many locked rooms and, indeed, he associates three of them-Leonora, Maisie, and Florence-with keys: the one that Leonora wears around her wrist is the focal point of her description, and it is this same key, entangled in Maisie Maidan's hair that brings the three women together in the corridor of the hotel (into and out of whose doors there is much secret ingress and egress); Maisie herself dies clutching a key in her hand. Moreover, Florence's locked bedroom door is charged with the irresistible attractiveness of a Pandora's box and, indeed, Dowell will take on all the pathos of an Epimetheus when at last the mysteries that lie behind it are revealed.

If we remain in mythic mode for a moment, we may recall that at the centre of Daedelus's labyrinth, built on the island of Crete, crouched the Minotaur, the monstrous by-blow of the unnatural amours of Pasiphaë, his mother, with a bull sent by Poseidon to Minos to be used as a sacrifice. The Minotaur, in turn, required the sacrifice of seven pure youths and maidens every nine years. Now this term-nine years -has a certain suggestive resonance within Dowell's story, being the period of the acquaintainceship of the two couples at the centre of the "four-square coterie" with which the tale begins (9), the period that elapses between Ashburnham's affairs with la Dolchiquita and Florence (44), and the period during which Leonora, we are told, did not enter her husband's room (136). ${ }^{4}$ Such over-determination links the monstrosity that dwells in the centre of the maze with the chaste but fascinated Dowell's terror of sexuality-a territory into which he claims never to have strayed. The maze, in this reading, becomes not only a prison, for mazes do imprison when they cannot be successfully read, but also a way of postponing indefinitely a confrontation with what is hidden at the centre. In other words, to be lost is to be relatively safe. ${ }^{5}$

9 Dowell, who makes in his text a slyly oblique reference to the Cretan original by including "Cnossos" among Florence's sundry, well-rehearsed, topics of conversation, certainly presents himself as a maze-walker: he calls attention to his habit, in Nauheim, of counting the steps between landmarks on his local perambulations; he confides that "the world is full of places to which [he] want[s] to return" (17), and he occasionally 
pictures himself or one of his companions rushing in panic through disorientating architectures.

But it is especially in the architecture of his narrative that Dowell manages daedalian feats of composition. His own apologia for the to-ing and fro-ing, the labyrinthine complexities of his story, we have already heard. In what follows, I should like to explore some of the techniques used to produce what Ford rather contentedly called in his 1927 dedication of the novel its "intricate tangle of references and cross-references" (5), words which, by the way, Max Saunders tells us he also used to describe his grandfather's much admired painting, "Work" (Saunders 402). Among these techniques may be numbered repetitions and parallel structures, incremental repetitions in and revisions of diegetical development, elements which provide a sort of blueprint of the subjective web of memory, connection and combination that make up Dowell's mind. These are complemented by the masterful use of digression and by recourse to multiple viewpoints, which are juxtaposed and/or placed in confrontation by the single reporting narrator and which embed in the very structure of the narration the unfathomable maze of human desire, the inextricable tangle of interpersonal relationships, in which the "four-square" coterie and its later triangular offshoots are enmeshed.

11 The first of these categories-the repetition of locutions ${ }^{6}$ - suggests doubleness, or what Peter Nicholls calls "belatedness" in describing the emphasis on twisted chronology in the work of modernists of the pre-war period, and is expressive of the dislocations inherent in subjective experience re-lived repeatedly through anamnesis. Here is Dowell, for instance, learning for the first time that his wife was for nine years his best friend's mistress and understanding, as he whirls the reader dizzyingly between past, present and future, that understanding will be deferred:

No, I remember no emotion of any sort, but just the clear feeling that one has from time to time when one hears that some Mrs. So-and-So is au mieux with a certain gentleman. [...] It was as if I thought, at that moment of a windy November evening, that, when I came to think it over afterwards, a dozen unexplained things would fit themselves into place. But I wasn't thinking things over then. I remember that distinctly. I was just sitting back, rather stiffly, in a deep armchair. That is what I remember. (73)

12 The reiterated assertion here of the clarity and distinction with which not thinking and not feeling are recalled is pure Dowell, as are Dowell's convoluted textual arrangements. His restatements and revisions of diegetical items repeatedly foreground his imperious overturning of the imperatives of temporal ordering. It is only when he is approaching the end of his story, having by this time initiated the reader into an extremely elaborate structure of discontinuous narration, of doublings and triplings back, of temporal leaps and omissions, that Dowell, drawing attention to the promiscuity of his chronology, demonstrates what the story would have been like had it followed a slavishly linear design: he lists events like so many featureless entries in an agenda (142). Of course, the sample he provides of this alternative system is irredeemably dull, having none of the energy of disorder, the gusto of the habitual chronological mayhem, which has kept the reader on his toes and to which he has become accustomed. Indeed, by the time he reaches this point in the narrative, the reader has grown thoroughly addicted to Dowell's uncompromising imitation of an inscrutable destiny-as far as the reader is concerned, Dowell's unsystematic system has become "one of those sinister jokes that Providence plays upon one" (43). He has 
grown used to the interruptions and the detours, the reminiscences, the tunnellings and driftings down streams of recollection and up corridors of association, in other words, to being lost in the narrative funhouse into which Dowell has lured him.

While they represent both a source and an expression of confusion and complication, these features of repetition and revision, these fugal patternings, also offer an alternative to the narrative design that Dowell's chaotic chronology cannot provide. They become the structural pillars of his narrative house which although not quite a "safe castle" (11), remains nonetheless upright. Certain simple parallelisms supply the larger framework of the structure: the deaths, for instance, which mark the end each part: in the first part, Maisie's death; in the second Florence's; in the fourth, Edward's; while the end of the third part brings the death of all of Leonora's hopes. Or the parallel suicides of Florence and of Edward-neither of which is prevented by a Dowell who in each case is in a position to intervene. Or again, the parallel revelations through unpremeditated speech of the desires which in their complex reticulations configure the text: Dowell's for Nancy, Edward's for Nancy, and Nancy's for Edward-Dowell remaining, as always, in this unsatisfactory triangulation, a kink in the geometry of love.

14 Examples of incremental retellings are more numerous and structurally more disconcerting: Ford, we know, was a proponent of textual surprise and of the progression d'effet. These periodic recrossings of the narrative path create a sort of textual template of the maze figure with its intersections, bifurcations, junctions and angles, leading everywhere but towards clarification. They are loci of iteration, figuring the notions of hesitation, choice, decisional fatality, but also the possibility of endless re-beginnings within the confines of a closed space: all the characters of the novel repeat patterns until death or death-in-life breaks the syndrome. Leonora, the novel's only true survivor, is allowed renewal but renewal which the narrator does his best to indicate will really be a variation on an earlier theme: that is, her new husband, too, will be unfaithful to her albeit more discreetly than Edward Ashburnham.

Thus, Dowell returns repeatedly to certain touch-points of the past to reveal about them what was previously concealed or misunderstood, to re-examine them from alternative viewpoints, or simply to rehearse their details obsessively, as an exorcism of trauma. Indeed, in remarks preliminary to the telling of his story, Dowell had hesitated between expiation and memorialisation as the motivational force behind the tale's articulation. His periodic revisitings of events lying at significant crossroads along his narrative itinerary create an impression of an errantry without telos, a looping quest that can only begin and end with an interrogation: the "isn't there any heaven where old beautiful dances, old beautiful intimacies prolong themselves?" (12) of Chapter I, which repeats itself incrementally in the penultimate chapter in the question, "is there any terrestrial paradise where, amidst the whispering of the oliveleaves, people can be with whom they like and have what they like and take their ease in shadows and in coolness?" (151). In other words, Dowell's narrative begins and ends with nostalgia for a paradise which never existed and which is itself pictured as a fruitless circling-as the figure of the dance in his first question implies and as the repetitive syntax of the latter example confirms. "I ask myself unceasingly," Dowell laments, "my mind going round and round in a weary, baffled space of pain-what should these people have done?" (148). 
16 I should like to pause here to mention four examples of revision whose intersections form nodes in the narrational labyrinth, two concerning events in which Dowell was directly involved and two being events to which he was not himself a party. That reexamined and re-told events may pertain either to his own life or to the unwitnessed lives of others has its significance:

17 - the excursion to Marburg;

18 - the receipt by Dowell of cables calling him back to England;

19 - the story of the Kilsyte case;

20 - the story of Edward's affair with la Dolciquita. ${ }^{7}$

21 Never in all of these retellings is the story we hear quite the same. New impressions or new perspectives are added, creating new configurations. The reader finds himself on a learning curve similar to that of the narrator who, because he writes his book over a period of two years, accumulates information as well as undergoing a certain amount of emotional wear-and-tear and changes opinion, as well as heart, as he continues his way. The reader, too, meets these incidents for the second or the third time having grown more experienced or wiser or, like Dowell, perhaps simply more weary, thus mirroring the narrator's voyage of discovery. As Max Saunders suggests, "Ford presents the novel's intricate tangle as a problem to be experienced [by the reader] rather than to be solved" (Saunders 439).

of course, other and contradictory effects grow out of these nodal occasions, these overlapping storylines. Despite the effect of replication of the narrator's experience in the mind of the reader, some repetitions lead, on the contrary, to the reader's withdrawal from the narrator's influence, if only because he begins to suspect that Dowell is a liar, a madman, or both. Repeated discrepancies, for instance, in the timing of Edward's all-important confession to Dowell seem to amount to wilful mystification, while two incompatible versions of Edward's reaction to Nancy's telegram are given within a few pages. ${ }^{8}$ Just as Dowell asks heaven what the protagonists of his story were to do, the reader begins to wonder what on earth he is to believe.

Ford uses juxtaposition or confrontation of point of view to extend the range of the labyrinth figure to include not only the intra-personal, but the interpersonal: not only is the narrator's mind a maze, but the relations between the characters, with their irreconcilable desires and expectations, are as well. A fine Dowellian jeremiad sums it up:

Not one of us has got what he wanted. Leonora wanted Edward and she has got Rodney Bayham, a pleasant enough sort of sheep. Florence wanted Bramshaw and it is I who have bought it from Leonora. I didn't really want it; what I wanted mostly was to cease being a nurse-attendant. Well, I am a nurse attendant. Edward wanted Nancy Rufford and I have got her. Only she is mad. It is a queer and fantastic world. Why can't people have what they want? The things were all there to content everybody; yet everybody has the wrong thing. (151)

Dowell's narrative attempts to trace the steps-or rather the missteps-by which Leonora, Edward, Florence, Nancy and he himself found themselves at this extraordinary pass-or, rather, impasse. Desires, too, of course, are lines, lines of intersubjectivity which, as Tom Stoppard has demonstrated in Arcadia, are rarely Euclidean. Lines of attraction and lines of repulsion, lines of pressure, pulling and tugging, rending and splitting, extending and retracting, struggling to inscribe themselves, straight and simple, from one point-or heart-to the other, but interfered 
with, peremptorily cut (or, as Dowell likes to say, "cut out") so that the satisfaction of meeting is eternally postponed or, as Dowell sees it, postponed until eternity. "You see," he explains, in a riotously genteel understatement, "the position was extremely complicated. It was as complicated as it well could be, along delicate lines" (85).

These "delicate" lines include marital strife, adulterous deception, incestuous desire, usurpation of hereditary rights, symbolic castration, blackmail, sexual incompatibility, frigidity and impotence, and other dainty matters of similar ilk. Dowell, in this particular maze of conflicting wills and wishes, occupies the position of Arachne, spinning the silken threads of the various confidences he has coordinated, occupying at least for the time of his story, the centre, instead of the periphery of things.

Thus he can juxtapose most brilliantly (we may recall Ford Madox Ford's own excruciating and exhaustive experimentations in conjugal disharmony) the piteously irreconcilable hopes of the Ashburnham couple, locked together in implacable opposition, forever misconstruing each other's motives, suspecting each other's intentions, abhorring each other's ideals and missing, at those rare moments when suddenly the channels clear and the possibility of their following parallel paths becomes just imaginable, the opportunity to join, to walk together along the same route. Everything (from the pigskin cases-that Leonora sacrifices her own pleasures to procure-which give Edward no pleasure, to the women she provides for him and who end up sacrificed) follows this same intractable pattern. Indeed, those who suffer such incompatibilities become adept at reading the visible signs of concealed betrayals: Leonora, we are told, "knew what it meant that she, when we all four walked together, had always been with me ten yards ahead of Florence and Edward" (123); she knows what it means when gaze meets gaze, when finger riffles finger lightly or when, seated at a round table, whose contours ought to minimize rivalry, Florence nevertheless calls out, "Avanti!"

Thus, Dowell has innumerable lines to track:

At any rate I think I have brought my story up to the date of Maisie Maidan's death. I mean that I have explained everything that went before it from the several points of view that were necessary-from Leonora's, from Edward's and to some extent, from my own. You have the facts for the trouble of finding them; you have the points of view as far as I could ascertain or put them. (120)

When the perceiving entities, with their resentments, agonies, and unsatisfied cravings, number three, four or even five, the lines multiply, the pattern intensifies, the telling grows increasingly intricate. Dowell must piece together a mosaic of experiences gleaned from his informants, Leonora, Edward and Nancy, with highlycoloured fragments of his own imagination fitted into the overall design. Furthermore, as he himself points out, there will always be the potential but unknown factor, the unascertained viewpoint; the tableau is never complete, the schema never entire. His elaborately wrought sequences of variant perspectives are perhaps especially useful as an exercise in predicating a hypothetically endless multiplication of possibilities. For a labyrinth, although closed, is at least suppositiously infinite. Dowell's characters are enclosed in it, notwithstanding their dreams of the horizon.

This second significant trope is elaborated in a section of the novel that functions rather as a set-piece, a passage apart, differing from the rest of the book insofar as its tone is neither ironic, parodic, nor hyperbolic, tropes that everywhere else work against interpretive unidimensionality. It comes just about mid-way through the novel 
(in Part III, Chapter i) when Dowell is meditating on Ashburnham's last passion, hesitating about whether to judge it culpable or to consider it the natural culmination of a lifetime's quest. He uses for the purpose of examining the nature of passion an extended metaphor of exploration, in which the (male) lover-for the question is avowedly seen only from a masculine point of view-dons his knapsack and sets out to broaden his outlook, to acquire new territories. These territories are in fact the alien hearts and minds of women, women who are so many enticing prospects, "so many objects on the horizon of the landscape that tempt a man to walk beyond the horizon, to explore" (79).

Dowell who, after all, in the course of this his first effort at storytelling has become a stout Cortez of discursive skills, shifts ever so slightly the burden of his trope: the horizon becomes a frontier separating mind from mind, open to the possibility of annexation:

He wants to get as it were behind those eye-brows with the peculiar turn, as if he desired to see the world with the eyes that they overshadow. He wants to hear that voice applying itself to every possible proposition, to every possible topic; he wants to see those characteristic gestures against every possible background. (79)

This yearning to penetrate, to traverse and overpass the borderline between being and being, is, despite Dowell's specific denials, sexual, but it is also spiritual, intellectual, emotional, creative. Dowell does not connect it, as he might, to the imaginative act of reconstruction which he himself is in the midst of accomplishing; instead, he ties the notion of spatial amplitude to the man of whom, in his own estimation, he is no more than the faint epigone-Edward Ashburnham. Edward, who surveys women as he surveys the horizon of his English estates, as though saying to himself, "all this is my land!" (26); Edward, for whom the conquest of Mrs Basil is like reaching "the depths of an unexplored wood" (118); Edward, whose desperation at the thought of being separated from Maisie is measured, repeatedly, by the "blue mountains and the sea and sunlit plains" that will lie between them (116); Edward, who even in the stranglehold of renunciation hopes that Nancy, his final love, will continue to be attached to him by an invisible five-thousand-mile-long thread of constancy. Edward's panoramic approach to passion is parodied by that of his pale imitator, Dowell, who also desires Nancy but only, as he admits, the way some people want to go to Carcassonne (84).

Yet just as the labyrinth is both a place of danger and one of sanctuary, the horizon offers both expansion and retraction. Indeed, it is by conquering the horizon that the hero finds himself imprisoned in the web of relationships. A series of tropic transpositions will exemplify the way in which such anastomotic connections are implied. The most telling figure is that of the lighthouse. ${ }^{9}$ It is introduced quite literally through Florence's Uncle John, John Dowell's namesake and, like him, apparently of the celibate persuasion, who during his trip round the world, generously if somewhat quixotically had himself rowed out to a lighthouse spied on the horizon in order to present its keepers with gifts of oranges (20). This literal lighthouse undergoes a metaphorical transformation shortly afterwards, becoming the vehicle in a figure of which Leonora's intensely blue eyes are the tenor, a figure heightened by a pun on one of the auxiliary elements of the description (the word "moving") and by the extension of the topographical trope to encompass the relationship between matter and mind: "Her eyes too were blue and dark .... And it was a most remarkable, a most moving glance, as if for a moment a lighthouse had looked at me. I seemed to perceive the swift questions chasing each other through the brain that was behind them" (29). 

opportunity to do so is during the crisis at Marburg when Leonora realizes that Dowell prefers a selective blindness to the burden of knowledge. Now, the sweeping lighthouse of her glance becomes something quite other: "She looked me straight in the eyes, and for a moment I had the feeling that those two blue discs were immense, were overwhelming, were like a wall of blue that shut me off from the rest of the world" (38). Thus does a horizon become a barricade and the prospect of motion crumble into inertia. When Leonora and Edward's own relationship is evoked much later, the spatial imagery again works ironically, with Dowell questioning whether it is necessary to give a detailed account of the couple's "progress towards complete disunion" (94). Going places and disintegrating have become the same thing. broad and rather tempting if indirect, invitation to listen-"This is the saddest story I have ever heard" (9)-to a tale whose superlative nature promises to be riveting. But within a few paragraphs of its opening, the text has become a sort of roll-call of the dead. We learn that half of the original cast, to whom we have just been introduced, have met their mortal end and, in Florence's case, these obituary proceedings will be repeated, rather gleefully, at least thrice more in the space of the first two chapters.

Somewhat later, the introduction of a new major character, "the girl," Nancy, provides a breath of fresh air, but it too is followed at a barely decent interval by the announcement of her death, an announcement, it must be added, that is itself a prevarication which will be gradually amended, but never in such a way as to permit Nancy Rufford to become a pleasantly open prospect in the narrative landscape. ${ }^{10}$ Into this doom-laden story, turning round and round on its own axis, ${ }^{11}$ an impression reinforced stylistically by Dowell's obsessive use of repetition, comes the relief of digressions, momentary apertures in the claustrophobic gyrating of the text. But the digressions, too, like the frequently used rhetorical device of aposiopesis which leaves Dowell's thoughts unfinished and dangling, operate both for and against the notion of openness. In the first case, although the digressions open new avenues of interest, they generally lead round once more to material that has been rehearsed and rehearsed again. In the second, the ellipses with which paragraphs occasionally refuse to conclude both suggest open-endedness and confront the reader with the inconclusive nature of all Dowell's discourse, the sort of hermeneutic cul-de-sac to which, from the beginning, he has hinted that he is leading us.

This same ambiguity seems to characterize the broadest horizon Dowell ever evokes: his dream of "the hand of God stretching out for miles and miles, with great spaces above it and below it" (53) and above which three figures are suspended. This roomy eidolon is, in fact, a hallucination of purgatory, an image of Dantesque judgment ${ }^{12}$ that veers erratically from compassion to retribution, from mercy to vengeance. Taken in conjunction with all the exclamatory invocations of the deity with which Dowell peppers his text ("Oh God!" "Just Heavens!" "God knows"), this picture of purgatory brings to mind the persistent but equally inconclusive treatment in the novel of the question of human destiny and Dowell's inability to discern whether a just providence reigns over it (Nancy's "Credo in unum Deum Omnipotentum") or whether human affairs proceed by a haphazard concatenation of accidents (Nancy's "Shuttlecocks!") (Saunders 441). 
37 I have been trying thus far to look at the ways in which two opposed but interpenetrating figures, the labyrinth and the horizon, provide a framework for the organisation of textual space in The Good Soldier. As Miriam Bailin suggests, the creation of such forms represents for Dowell, as the architect of the story, a consolation for all the social and moral stabilities that have disappeared from his world. ${ }^{13}$ Ford himself had written in the years just preceding the composition of the novel of how contemporary life was "more and more losing the sense of a whole, the feeling of a grand design, of the co-ordination of all Nature in one great architectonic scheme." Modern man was increasingly preoccupied by "an infinite number of little things, with no time to arrange them in [his] mind ..." And this loss of a sense of an over-all purpose to the universe threw the bewildered individual more and more in upon himself, seeking "comprehension of that which is not understandable..." (Memories 68-69).

Dowell's displacements in space, in this context, become an emblem of the condition of modern man-uprooted, physically and spiritually, with no clear (read: Victorian) signposts to point the way. Indeed, the most Dickensian moment in the novel is a failed attempt by Nancy Rufford to play Esther Summerson to her fallen mother's Lady Dedlock. During the crisis that occurs during her last days at Bramshaw, Nancy learns that Mrs Rufford is still alive and determines to rescue her from what she imagines to be death in the northern snow. But unlike Esther, Nancy never gets beyond the chair in which she fantasizes such heroics.

Nancy's dream of action remains just that-a dream; and Dowell, although he moves a great deal, may be said never to leave the armchair of his mind. It is true that he passes through Paris and Stamford, Nauheim and Hampshire, that he crosses oceans and continents, but no sooner does he evoke the landscapes through which he travels than they are de-realized by the impressionism of his descriptions: thus, for example, does the tower at Beaucaire call to his mind the Flatiron Building in Manhattan, a structure to which it bears no resemblance, and the Prussian countryside become a pointillist painting in which spots of colour distract from a perception of the whole. Now there is nothing new about saying that fictional topographies may be read symbolically, as a projection of one or another set of values or emotions. But in The Good Soldier there is such a collapsing of the interface between external and internal reality that in a sense, travel as he might, Dowell always remains in the same place, or to put it another way, his inner landscape is so powerfully present that it shapes whatever he sees.

Describing the scene in which he finds himself on the night of his wife's death, Dowell depicts a "pink effulgence" emanating not so much from the lamps in the hotel lounge where he is sitting as from his own sense of shock and deliverance. Through this roseate haze bob "floating globes" which are the heads of the three German officials who surround him, their voices variously and picturesquely described as dropping pellets of suet, rasping revolver shots and the drone "of an unclean priest reciting from his breviary in the corner of a railway-carriage" (75). The comic verve of such notations efficiently undercuts the solemnity of the occasion, translating Dowell's fundamental indifference to the sorry end of "poor Florence." But as building blocks of verisimilitude they hardly make the grade, unless of course the object be to posit the reality of the subjective vision informing his account. How much more visually vivid is the picture that Dowell paints for us shortly afterwards of a scene that he never witnessed, when Florence crept up on Edward Ashburnham and his ward Nancy only to hear her lover unexpectedly declare his devotion to the girl: 
Anyhow, there you have the picture, the immensely tall trees, elms most of them, towering and feathering away up into the black mistiness that trees seem to gather about them at night; the silhouettes of those two upon the seat; the beams of light coming from the Casino, the woman all in black peeping with fear behind the treetrunk. (77) in a comfortable lounge chair at his hotel, is perhaps related to the place that Ford was evoking when he wrote that "the heart of another is a dark forest" (Memories xiv). And it is through this same sombre woodland that Dowell's narrative coach has been plummeting from the very beginning. Trying to characterise the relationship between the two couples with whom his story began and, through them, the society which they represent, he had hesitated between the image of the minuet-a safely regulated, if obsolete, ritual of social intercourse-and that of a "prison full of screaming hysterics tied down so that they might not outsound the rolling of our carriage wheels as we went along the shaded avenues of the Taunus Wald" (12). Well, it is into such a carriage that Dowell has bundled his reader for a journey through the byways of his mind, through which filter sounds of music but also cries of madmen.

The journey is disconcerting and circuitous. The narrative carriage encloses us but dictates no sense of direction. We are confined, but we have vistas. And this seems appropriate for a story that hesitates as to its genre, denying its affiliation with tragedy here, yet proclaiming it there, all the while nipping mournfulness in the bud with relentless irony and undercutting sentiment through the parodic adoption of the techniques of melodrama. The text returns again and again to the paradox of knowledge: that it recedes as one advances towards it, that the path splits at the very moment when the way seems clear. If it is in the nature of narration to conceal as it strives to reveal, if "no story ever bring[s] the things it narrates wholly into the open" (Miller Topographies 8), the telling of Dowell's saddest story seems to prolong the cognitive functions associated with a number of his characters: that is, the discovery of meaning through the act of expression. In this sense, his story is a performance rather than the expression of a signification that has or can be fixed. It means as long as it moves. And the way it moves is also its meaning. But, beyond that, it does offer what Dowell posits as desirable when he projects onto Edward Ashburnham the dream of seeing the world through the eyes of another-the hoped-for, the necessary, the impossible relationship, what Ford called the "odd vibration" that makes the reader feel he is passing through an experience (Ford 1995, 264).

Ford described, in Memories and Impressions, the curious technique of his beloved grandfather, Ford Madox Brown, who always began a picture by painting the eyes of the central figure. Thereafter, however much he might alter the rest of the canvas, the eyes thus painted remained untouched (Ford 1911, 226-227). And so on the canvas of Ford's masterpiece, the reader's attention is constantly directed back to the one pair of eyes to which the novel never grants a descriptive treatment-those of Dowell himself. For, of course, Dowell's eyes are there, smiling out at us, invisible and unavoidable, infusing, in the extraordinary journey that is The Good Soldier, every view, every step, and every emotion. 


\section{BIBLIOGRAPHY}

Bailin, Miriam. “'An Extraordinary Safe Castle': Aesthetics as a Refuge in The Good Soldier.” Modern Fiction Studies. 30: 4 (Winter 1984): 621-636.

Cousineau, Tom. Ritual Unbound:Reading Sacrifice in Modernist Fiction. Newark: University of Delaware Press, 2004.

Ford, Ford Madox. The Good Soldier. Ed. Martin Stannard. New York: Norton, 1995.

--- Memories and Impressions: A Study in Atmospheres. New York: Harper, 1911.

--- "Provence." The Ford Madox Ford Reader. Ed. Susan Stang. New York: Ecco Press, 1986.

Gaskell, Elizabeth Cleghorn. Cranford. 1853. Harmondsworth: Penguin, 2006.

Gordon, Ambrose Jr. “At the Edge of Silence: The Good Soldier as 'War Novel'”. Modern Fictions Studies 9: 1 (Spring 1963): 67-77.

Hessler, John. "Dowell and The Good Soldier: The Narrator Re-Examined." The Journal of Narrative Technique 9:1 (Winter 1979): 53-60.

Hynes, Samuel. “The Epistemology of The Good Soldier". In Ford Madox Ford, The Good Soldier. Ed. Martin Stannard. New York: Norton, 1995, 310-317.

Miller, J. Hillis. Ariadne's Thread: Story Lines. New Haven, Yale University Press, 1992.

---. Topographies. Stanford: Stanford University Press, 1995.

Nicholls, Peter. Modernisms: A Literary Guide. London: Macmillan, 1995.

Levenson, Michael. A Genealogy of Modernism: A Study of English Literary Doctrine, 1908-1922.

Cambridge: Cambridge University Press, 1984

Saunders, Max. Ford Madox Ford: A Dual Life. Vol. 1. Oxford: Oxford University Press, 1996.

Stoppard, Tom. Arcadia. 1993. London: Faber and Faber: 2000.

\section{NOTES}

1. For an example of both contradiction and suspicious chronology: Dowell claims several times that Ashburnham's "final outburst" took place on the evening before Nancy left for Ceylon and several times that it occurred while the girl was on her way to Brindisi. For an example of outrageous assertion: Dowell alleges that for several years after their marriage, Edward and Leonora did not know "how children are produced" (99). As an example of both a tease and a riddle: what were Edward Ashburnham's last words and why did he slit his throat with a pen knife rather than use one of the many fire-arms in his gunroom? Was the latter choice due to the fact that Dowell, in his own fantasies about dying for love, sees cutting one's throat as an appropriate gesture (62)?

2. An anatomical term, anastomosis describes interconnection between two vessels, channels or distinct branches of a branching system, as for example the connections between arteries and veins.

3. Indeed, Florence's maiden aunts, with their exacerbated gentility, are not unlike the Jenkyns sisters and their circle in Cranford. Further fleeting references to Mrs Gaskell's novel may be found: the rather singular surname "ffoulkes" which serves in a comic passage in the earlier 
novel as an exemplar of snobbery makes its way into Ford's novel in a similar connection; and another echo: Miss Matty and Miss Pole remembering the "menuet de la cour" which they danced in their girlhood and which recalls Dowell's famous image of the four-square relationship he and his wife formed with the Ashburnhams.

4. Coincidentally (?), the speaker of Ford's poem "On Heaven" waits nine years to be joined by his love.

5. Many critics have discussed Dowell's stategies of avoidance, among them Hessler who speaks of Dowell's "labyrinthine series of retreats from self-confrontation" and Bailin who studies how Dowell's aesthetic concerns are a means of postponing recognition.

6. The device is endemic. Moreover, the repetitions often create parallelisms. An example: "I call this the Saddest Story, rather than 'The Ashburnham Tragedy', just because it is so sad, just because there was no current to draw things along to a swift and inevitable end. There is about it none of the elevation that accompanies tragedy; there is about it no nemesis, no destiny" (109, emphasis added).

7. Here are the revisions:

- the excursion to Marburg: recounted in I,iv, as Dowell originally experienced it but interrupted and then taken up again in I,v, after an interval during which details of Ashburnham's amorous career and of Maisie's pathetic death have been revealed, thus changing the impact of the episode itself considerably, then returned to twice more in IV,i, when Dowell re-tells the Protest scene as it must have been experienced by someone else, by Leonora, and when he pauses to consider how she might have changed the course of his personal history by handling the situation differently; - the receipt by Dowell of cables calling him back to England: mentioned twice in I,ii, where the receipt of the cables is surrounded with information just enigmatic enough to tantalise the reader with all he does not know; then again in IV,ii, where Dowell's speculations upon receiving them - speculations which will prove pathetically mistaken - as to their meaning are given; they are then treated again, this time with insight into the circumstances that brought about Edward's decision to send his cable and Leonora's decision to follow it with one of her own, in IV, iv.

- the story of the Kilsyte case: this incident, which occurred years before the meeting between the Dowells and the Ashburnhams, is mentioned first in I,v and discussed intermittently for the rest of that chapter; then in III,iii, where it is described in greater detail; and mentioned yet again but this time briefly and in relation to Edward's next adventure with the Dolciquita in III, iv;

- the story of Edward's affair with la Dolciquita: mentioned in I,v, and retold in greater detail and with greater irony in III, iv.

8. For Edward's outburst, see footnote 1, above. On the last page of the novel, Ashburnham is described as reading the telegram "in complete silence" whereas a half-dozen pages earlier, he is said to have considered that "her quite atrocious telegram from Brindisi was only another attempt to ... prove that she had feelings creditable to a member of the feminine commonweal" (156).

9. A second figure, similarly used, is that of the sailing vessel, which in the course of the novel mutates from an image of safety and beauty connected first to the "four-square coterie" of the two couples and then to the serenely youthful Nancy, but which later becomes the destructive "fireships" of the Ashburnham couple.

10. On page 52, Edward and Nancy and Florence are said to be "all dead together"; on page 84, we are told that Dowell thought intensely about Nancy until "her worse than death"; on page 133, we learn that it "would be much better for Nancy Rufford if she were dead." 
11. Ambrose Gordon Jr. uses this figure in relation to the date of 4 August: "The series of repeated dates serves, then, as an axis, a still point, about which the book slowly turns-or it is like a cracked disk, a single horrible moment that repeats itself endlessly" (70).

12. Tom Cousineau discusses the relationship between The Good Soldier and the story of Paolo and Francesca.

13. "[Dowell's text] is a shapely and ordered arrangement of confused passageways leading in many directions at once. Rather than 'a method to conceal art,' it can be seen as an artistic concealment, or at least containment, of the Minotaur within-the imposition of a controlled form upon the chaos of a world from which the protection of conventional structures of meaning has been withdrawn." (Bailin 623)

\section{ABSTRACTS}

This study attempts to examine the ways in which two apparently opposed but interpenetrating figures, the labyrinth and the horizon, provide a framework for the organisation of textual space in Ford Madox Ford's The Good Soldier. Exploring occurrences of each of these tropes, from the labyrinthine nature of the narrator's method to the metaphors of sweeping spatiality associated with his hero's amorous experimentations, it suggests that both figures involve movements of expansion and enclosure, of connection and confinement, but that the resulting sense of aporia is mitigated by the energy of narrative pattern-making. Configurations of the maze and of open space not only allow the narrator to express his "saddest story" but create a form in which to contain it.

Cette étude tente de mettre en lumière la manière dont deux figures en apparence opposées mais qui s'interpénètrent, le labyrinthe et l'horizon, fournissent un cadre à l'organisation de l'espace textuel dans The Good Soldier de Ford Madox Ford. Analysant les occurences de chacun de ces tropes-de la nature labyrinthique de la méthode du narrateur jusqu'aux métaphores d'élargissement de l'espace associées aux expérimentations amoureuses de son héros-elle suggère que les deux figures impliquent des mouvements d'expansion et de contraction, d'ouverture et d'enfermement, mais que l'aporie qui en résulte est contrebalancée par la vigueur du schéma narratif. Les configurations du labyrinthe et de l'horizon non seulement permettent au narrateur de construire sa "très triste histoire", mais d'élaborer une forme susceptible de la contenir.

\section{INDEX}

Keywords: chronology, hermeneutic, impressionism, maze, mystification, narration, nonlinearity, repetition, riddle, verisimilitude

Mots-clés: chronologie, discontinuité, énigme, herméneutique, impressionnisme, labyrinthe, mystification, narration, répétition, vraisemblance 
AUTHORS

ELLEN LEVY

Maître de conférences

Université de Toulouse II - Le Mirail

levy@univ-tlse2.fr 